\title{
Current Knowledge of the Social Wasps (Hymenoptera: Vespidae) in the State of Piauí, Brazil
}

\author{
Agda Alves da Rocha ${ }^{1}$ \& Orlando Tobias Silveira ${ }^{2}$
}

1. Universidade Federal da Bahia, e-mail: rocha.agda@gmail.com (Autor para correspondência ${ }^{\bowtie}$ ). 2. Museu Paraense Emílio Goeldi, e-mail: orlando@museu-goeldi.br.

\section{EntomoBrasilis 7 (2): 167-170 (2014)}

Abstract. New records of social wasps in the State of Piauí are presented, contributing to an increased knowledge of this group in this poorly studied region. This study documents new occurrence records for 12 social wasp species and extends their distribution.

Keywords: Caatinga; Distribution; Inventory; Northeast Region; Polistinae.

\section{Atualização do Conhecimento Sobre Vespas Sociais (Hymenoptera: Vespidae) no Estado do Piauí, Brasil}

Resumo. São apresentados novos registros da fauna de vespas sociais em localidades do Piauí, contribuindo para o aumento do conhecimento desse grupo de organismos na região. Este estudo registra a ocorrência de 12 novos registros de vespas sociais, ampliando suas distribuições.

Palavras-chave: Caatinga; Distribuição; Inventário; Região Nordeste; Polistinae.

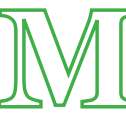
any areas of Brazil lack the most basic biodiversity studies, particularly in the case of invertebrates. In order to develop any effective conservation proposals, it is first of all necessary to acquire knowledge of the species that occur in a particular area (MeLo et al. 2005). This taxonomic baseline is obtained by conducting biodiversity inventories.

In Brazil the wasp family Vespidae is represented by the subfamily Polistinae, which has 21 described genera and more than 300 species (CARPENTER \& Marques 2001; Silveira 2010). According to CARPENTER (1993) this subfamily has three tribes in Brazil: Mischocyttarini (made up of the genus Mischocyttarus), Polistini (consisting of the genus Polistes) and Epiponini (with 19 genera) (CARPENTER 2004). Wasps are ideal models for studying the evolution of social behavior, as different species of this family exhibit varying degrees of sociality, from solitary to eusocial species. This diversity in sociality means that wasps can be studied to develop an understanding of key issues about the evolution of social behavior (ITô 1993).

The State of Piauí is one of the least studied Brazilian States. Among the areas defined by the Ministry of the Environment, the municipalities of Canto do Buriti and São João do Piauí were examples of those with insufficient knowledge. Canto do Buriti and Serra das Confusões/ Parque Nacional da Serra da Capivara complex were considered priority areas for research (MMA 2002). There is a clear need to conduct more comprehensive inventories that can contribute to increasing knowledge of this group of insects and support future studies of behavior and biology. The aim of this study was to provide new information on the occurrence of social wasps in parts of the State of Piauí.

Data were collected from two municipalities in Piauí: Dom Expedito Lopes and Canto do Buriti (Figure 1).
The municipality of Dom Expedito Lopes is located $288 \mathrm{~km}$ from Teresina, in the southeastern corner of Piauí and Canto do Buriti is located in the southwest, $405 \mathrm{~km}$ from the capital (IBGE 2014a, b). Wasp inventories were conducted as part of the activities of the Grupo de Estudo do Ecótono Caatinga-Cerrado (GEECACE) and the research project "Entomofauna of Priority Areas for Conservation of the State of Piauí," funded by Fundação de Amparo à Pesquisa do Estado do Piauí (FAPEPI N. 20203.0822/2009). In Dom Expedito Lopes, the inventories took place in a property of the Água Mineral Manaíra company ( $\left.6^{\circ} 56^{\prime} 32^{\prime \prime} \mathrm{S}, 41^{\circ} 41^{\prime} 46^{\prime \prime} \mathrm{W}\right)$ and in Canto do Buriti the inventory took place in properties located $8 \mathrm{~km}$ from the town center ( $\left.08^{\circ} 09^{\prime} 63^{\prime \prime} \mathrm{S}, 042^{\circ} 55^{\prime} 50^{\prime \prime} \mathrm{W}\right)$. All data were collected in the dry season. Surveys were conducted in October 2009 in Dom Expedito Lopes $\left(14^{\text {th }}, 15^{\text {th }}, 16^{\text {th }}\right.$ and $\left.17^{\text {th }}\right)$ and in October $2010\left(10^{\text {th }}, 11^{\text {th }}\right.$ and $\left.12^{\text {th }}\right)$ in Canto do Buriti. Each area was inspected from 6:00 A.M. to 6:00 P.M. by two collectors. Collectors captured insects in flight or on the vegetation, using entomological nets and vials containing ethyl acetate. In Canto do Buriti two collectors searched for nests during two days using the Active Search Method along trails in the vegetation. Nests were collected using protective beekeeper clothing.

The collected insects were mounted, labeled and deposited in the Invertebrate Collection of the Museu Paraense Emilio Goeldi (MPEG).

Onehundredandeightysevenindividuals of socialwaspsbelonging to 12 species in six genera were collected: Agelaia, Brachygastra, Polistes, Polybia, Protonectarina and Protopolybia (Table 1).

Of these, Polistes canadensis canadensis (Linnaeus), Agência(s) de Financiamento: Fundação de Amparo à Pesquisa do
Estado do Piauí. 


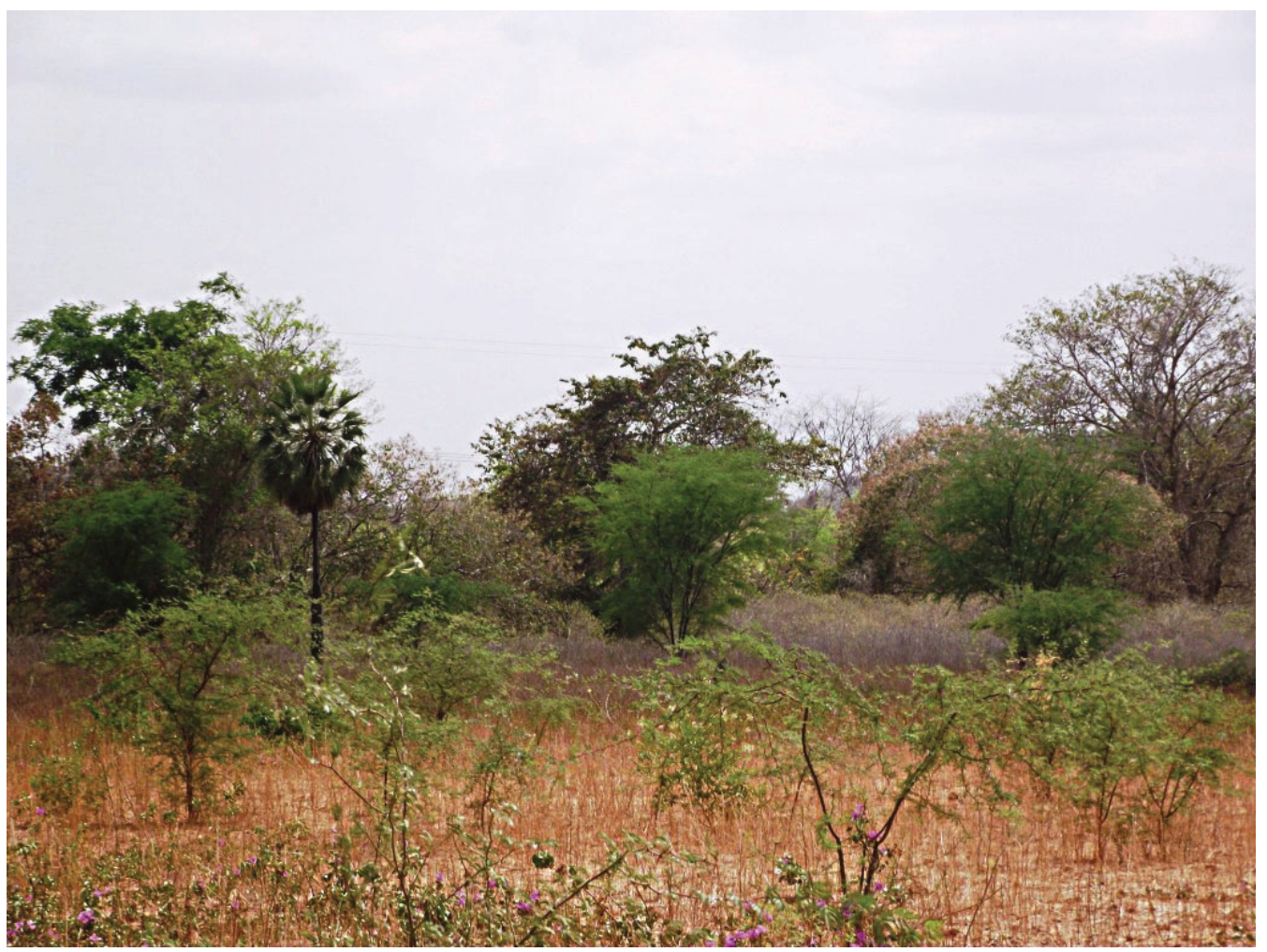

Figure 1. Landscape of the study area in the state of Piauí: Canto do Buriti - Piauí (Picture: A. A. Rocha).

Table 1. Diversity of Social Wasps (Hymenoptera, Vespidae) at two sites in the State of Piauí, Brazil.

\begin{tabular}{|c|c|c|c|}
\hline \multirow{2}{*}{ Tribe } & \multirow{2}{*}{ Specie } & \multicolumn{2}{|c|}{ Locality } \\
\hline & & DEL* & $\mathrm{CB}^{* *}$ \\
\hline \multirow{2}{*}{ Polistini } & Polistes canadensis canadensis (Linnaeus) & $\mathrm{F}$ & - \\
\hline & Polistes (group) canadensis sp. & $\mathrm{F}$ & - \\
\hline \multirow{10}{*}{ Epiponini } & Agelaia pallipes (Olivier) & $\mathrm{F}$ & $\mathrm{F}$ \\
\hline & Brachygastra lecheguana (Latreille) & $\mathrm{F}$ & $\mathrm{N}$ \\
\hline & Polybia ignobilis (Haliday) & $\mathrm{F}$ & $\mathrm{F}$ \\
\hline & Polybia (group) occidentalis sp. 1 & $\mathrm{~F}$ & $\mathrm{~F}, \mathrm{~N}$ \\
\hline & Polybia (group) occidentalis sp. 2 & $\mathrm{~F}$ & - \\
\hline & Polybia paulista (Ihering) & $\mathrm{F}$ & - \\
\hline & Polybia ruficeps xanthops Richards & $\mathrm{F}$ & - \\
\hline & Polybia sericea (Olivier) & F & $\mathrm{F}, \mathrm{N}$ \\
\hline & Protonectarina sylveirae (Saussure) & - & $\mathrm{F}$ \\
\hline & Protopolybia exigua (Saussure) & $\mathrm{F}$ & $\mathrm{F}, \mathrm{N}$ \\
\hline
\end{tabular}

* Dom Expedito Lopes - PI ** Canto do Buriti - PI (F): Collected in flight or on vegetation, (N): Collected in the nest.

Brachygastra lecheguana (Latreille), Polybia ignobilis (Haliday), Polybia paulista (Ihering) and Polybia sericea (Olivier) are widely distributed across Brazil and throughout the northeast region (RICHARDS 1978; ANDENA \& CARPENTER 2014). Agelaia pallipes (Olivier), Protonectarina sylveirae (Saussure) and Protopolybia exigua (Saussure) are widely distributed across Brazil, but have only been recorded from two northeast States: Bahia and Ceará (Richards 1978; ANDENA \& CARPENTER 2014). Polybia ruficeps xanthops Richards has been recorded in the States of Mato Grosso, Minas Gerais, Ceará, Bahia and Rio Grande do Norte (Richards 1978; ANDENA \& CARPENTER 2014). This species has also recently been recorded from the State of São Paulo (Gomes \& Noll 2009; TanaKa-Junior \& Noll 2011).

Richards (1978) recorded the occurrence of Polybia depressa (Ducke) and Synoeca virginea (Fabricius) in Piauí. More recently ANDENA \& CARPENTER (2014) added another two species to those recorded from Piauí: Apoica pallens (Fabricius) and
Brachygastra scutellaris (Fabricius). According to these authors social wasps represent $3 \%$ of the fauna in northeastern Brazil.

Considering the insects collected, both in flight and on the vegetation in Dom Expedito Lopes, a total of 102 individuals were recorded, distributed among 11 species and five genera. In Canto do Buriti, 85 individuals were recorded, distributed among six species and four genera.

During the study period a total of twenty one social wasp nests were located in Canto do Buriti, 14 of which were active. These active nests belonged to four species of which three $(B$. lecheguana, Polybia (group) occidentalis sp. 1 and $P$. sericea) have phragmocyttarus nests i.e. the nest is fully secured to the substrate without the presence of stems. P. exigua has stelocyttarus calyptodomous nests which are stalked with numerous combs (RICHARDS \& RichARDS 1951) (Figure 2). 

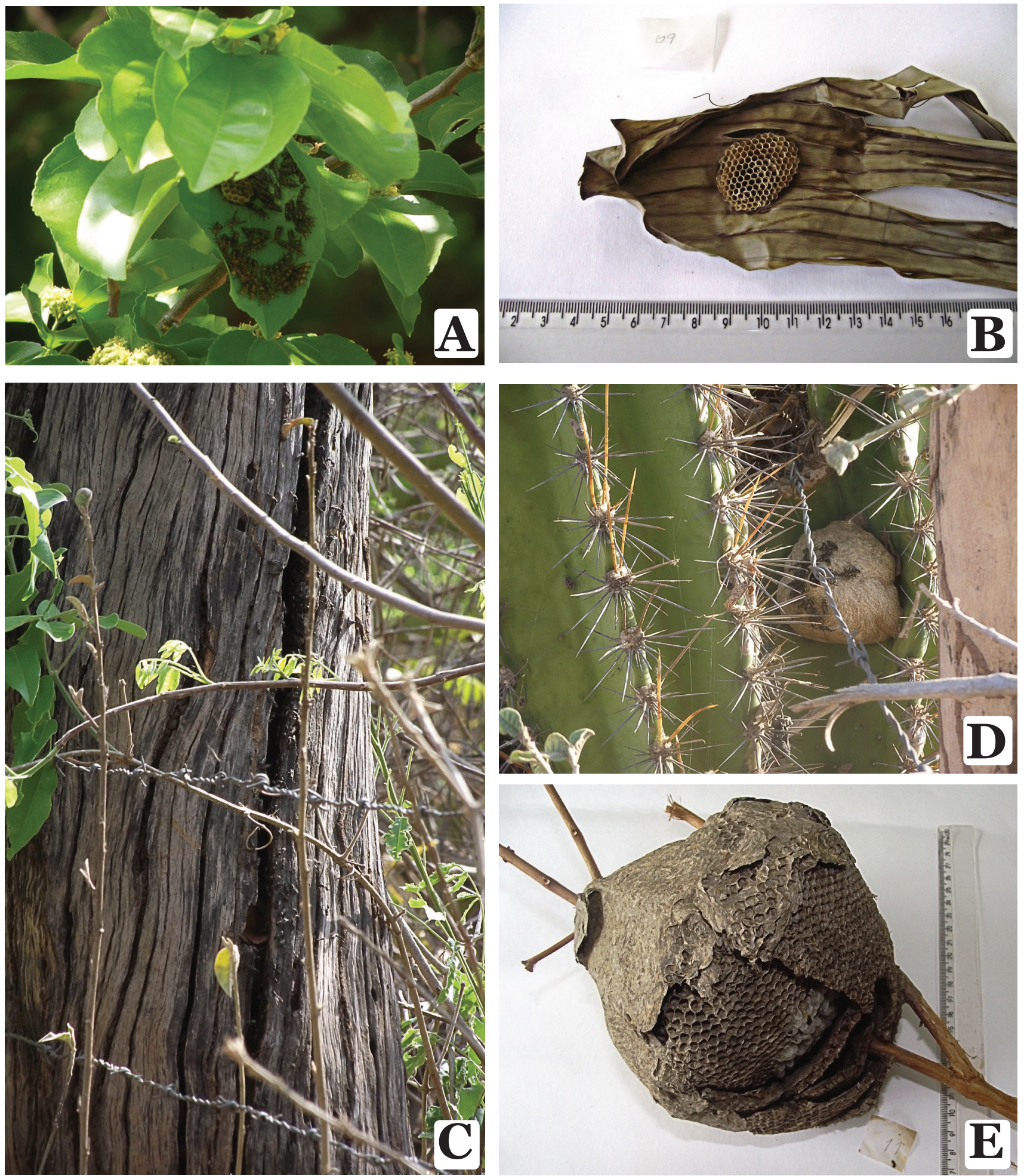

Figure 2. Nests of social wasps collected in Canto do Buriti - Piauí: A) Protopolybia exigua (Saussure) on a leaf of Ziziphus joazeiro Mart. (Rhamnaceae); B) Protopolybia exigua (Saussure) on a leaf of Musa sp. (Musaceae); C) Polybia (group) occidentalis sp. 1 on a fence post; D) Polybia (group) occidentalis sp. 1 in Cereus jamacaru DC (Cactaceae); E) Brachygastra lecheguana (Latreille). (Picture: A. A. Rocha).

This study presents new occurrences of 12 social wasp species in Piauí. Our findings extend the species distributions and increase the number of species recorded in Piauí to 16. This increase may be an indication that the richness is probably higher in the regions studied and that Piauí may well contain a number of additional (as yet unrecorded) social wasp species. More comprehensive studies are needed in order to increase the knowledge of wasp species in Piauí, contributing to increased knowledge of the diversity in northeastern Brazil.

\section{ACKNOWLEDGEMENTS}

The authors thank the students R. Nascimento, A. Soares, M. E. Brito and D. Carvalho for their help during the field activities.

\section{REFERENCES}

Andena, S.R. \& J.M. Carpenter, 2014. Checklist das espécies de Polistinae (Hymenoptera, Vespidae) do semiárido brasileiro, p. 169-180. In: Bravo, F. \& A. Calor (Eds.). Artrópodes do Semiárido: biodiversidade e conservação. Feira de Santana, Printmídia, 298p.

Carpenter, J.M., 1993. Biogeographic patterns in the Vespidae (Hymenoptera): Two views of Africa and South America, p. 139-155. In: Goldblatt, P. (Ed.). Biological relationshipes between Africa and Africa and South America. New Haven, Yale University Press, 630p.

Carpenter, J.M., 2004. Synonymy of the genus Marimbonda Richards, 1978, with Leipomeles Moebius, 1856 (Hymenoptera: Vespidae: Polistinae), and a new key to the 
genera of paper wasps of the new world. Americam Museum Novitates, 3456: 1-16.

Carpenter, J.M. \& O.M. Marques, 2001. Contribuição ao Estudo dos Vespídeos do Brasil. Série Publicações Digitais, Departamento de Fitotecnia, Universidade Federal da Bahia, 3, CD-ROM.

Gomes, B. \& F.B. Noll, 2009. Diversity of social wasps (Hymenoptera, Vespidae, Polistinae) in three fragments of semideciduous seasonal forest in the northwest of São Paulo State, Brazil Revista Brasileira de Entomologia, 53: 428431.

IBGE, 2014a. IBGE Instituto Brasileiro de Geografia e Estatística. Dom Expedito Lopes. Accessible at: <http://cod.ibge.gov. br/1GRU>. Access: March/o3/2014.

IBGE, 2014b. IBGE Instituto Brasileiro de Geografia e Estatística. Canto do Buriti. Accessible at: < http://cod.ibge.gov.br/9YQ>. Access: March/o3/2014.

Itô, Y., 1993. Behaviour and Social Evolution of Wasps, The Communal Aggregation Hypothesis. Oxford, Oxford University Press, 159p.

Melo, A.C., G.M.M. Santos, J.D. Cruz \& O.M. Marques, 2005. Vespas Sociais (Vespidae), p. 243-257. In: Juncá, F.A., L. Funch \& W. Rocha (Eds.). Biodiversidade e Conservação da Chapada Diamantina. Brasília, Ministério do Meio Ambiente, 411p.
MMA, 2002. Ministério do Meio Ambiente, dos Recursos Hídricos e da Amazônia Legal. Avaliação e Ações Prioritárias para a Conservação da Biodiversidade da Caatinga. Universidade Federal de Pernambuco. Brasília, Conservation International do Brasil e Fundação Biodiversitas, 404p.

Richards, O.W., 1978. The social wasps of the Americas excluding the Vespinae. London, British Museum (Natural History), 580 .

Richards, O.W. \& M.J. Richards, 1951. Observations on the social wasps of South America (Hymenoptera; Vespidae). Transactions of the Royal Entomological Society London, 102: 1-170.

Tanaka-Junior, G.M. \& F.B. Noll, 2011. Diversity of Social Wasps on Semideciduous Seasonal Forest Fragments with Different Surrounding Matrix in Brazil. Psyche: A Journal of Entomology, 2011: 1-8.

Silveira, O.T., 2010. On Richards concept of Mischocyttarus undulatus (Ducke), with the description of a new species of the group of $M$. iheringi Zikan (Hymenoptera, Vespidae). Studies on Neotropical Fauna and Environment, 45: 55-59.

Recebido em: 14/o3/2014

Aceito em: 28/05/2014

Como citar este artigo:

Rocha, A.A. \& O.T. Silveira, 2014. Current Knowledge of the Social Wasps (Hymenoptera: Vespidae) in the State of Piauí, Brazil. EntomoBrasilis, 7 (2): 167-170.

Acessível em: doi:10.12741/ebrasilis.v7i2.424
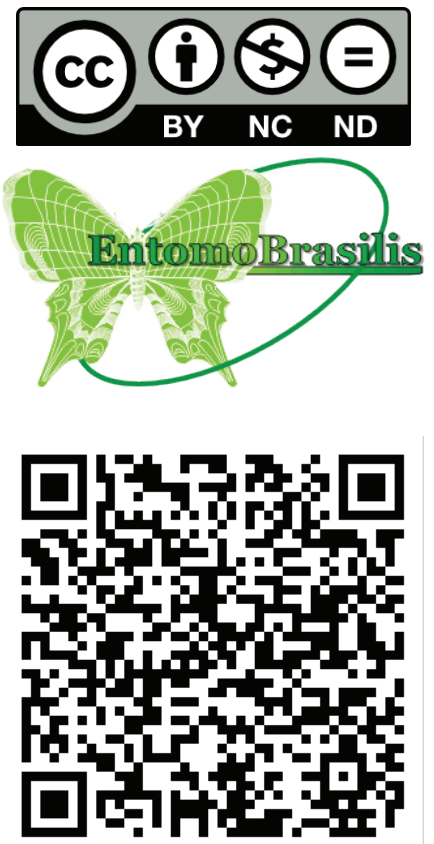